\title{
BOX OF TRADITIONAL GAMES:
}

\section{A MATCHING OF TOURISM AND MALAYSIAN CULTURES}

\author{
Mohd. Fadly Bin Lamri ${ }^{1}$; Mohamad Zulhilmy Bin Mohamad Yusop ${ }^{2}$; Nur Bazilah Binti Khairudin ${ }^{3}$ \\ ${ }^{2}$ Department of Tourism and Hospitality \\ Politeknik METrO Kuantan (PMKu) \\ Pahang, Malayisa \\ 1'akuceroi@gmail.com; ${ }^{2}$ reactivatezul@gmail.com; ${ }^{3}$ bazilahk@gmail.com
}

Box of traditional games is a product that combines five games in one box and price. Five games that were selected are dam haji (checkers), ceper (bottle steel cap), batu seremban (tossing stone), guli (marble) and gasing (tops spinning) which commonly played in Malaysia and some parts of the world. This product was created so that traditional games will not be outdated, as technology developments are the latest trend to attract people towards the modern game. According to the survey, it is shown that Malaysians nowadays typically the gen-Y still do not know the names and types of traditional games that have been played since time immemorial. In fact, some people even do not know how to play this traditional game. People are more inclined towards technology than traditional. The product is easy to be used; by opening the game box manufacture, choosing the gaming equipment required and referring to the game's instructions provided. In a survey that has been done by 50 respondents of students, local people and tourists. In product's demonstration, respondents think that this product can be marketable and the buyers will be enjoyed playing it. Overall, the respondents provided positive feedback. This product created for people to recognize the traditional game based in Malaysia in a box that has the right innovation. The game is an innovation that will be one of the most interesting products, easy to bring and convenient to play for all ages. The game is also very suitable for foreign tourists to recognize and play five traditional games found in the box. Informally the Malaysia's Pahang State Tourism Board is looking forward to discuss with the researchers and the polytechnic to work further in using the box as a tourist souvenir during the campaign of Visit Pahang Year 2017. The overall conclusion of the study showed that the box of traditional games has a high chance to penetrate the market in Malaysia and abroad. Hopefully, these traditional games stored in this innovative box will be played and not be forgotten by our next generation.

Keywords: box of traditional games, dam haji (checkers), ceper (bottle steel cap), batu seremban (tossing stone), guli (marble) and gasing (tops spinning)

\section{INTRODUCTION}

Is not a new story that traditional game has been forgotten because of the occurrence of the rapid development of gadgets technology and the addition of a virtual game application (app), as said by the Senior Curator of the National Museum of Malaysia, Noraini Basri (Utusan, 2015). Based on that, this product has been introduced and created with a good choice of wood to produce the storage box that will make it lighter and easier to bring along. Inside the box, it is divided into five (5) parts in one box and filled with five (5) different types of traditional games which are (i) dam haji (checkers); (ii) ceper (bottle steel cap); (iii) batu seremban (tossing stone); (iv) guli (marble); and (v) gasing (tops spinning). The surface of the box is drawn according to the pattern of board games of dam haji. With this new innovation, it will be able to attract attention and exciting the young generation and public, especially to kids and foreign tourists.

The purpose of this research is to curb the problem of traditional game that has been forgotten recently by the existence of modern games. Other than that, this research has brought to alert people about the importance of culture and heritage. As we know, the problem of addiction on modern technology has become one of the main issues in Malaysia and this study has become an alternative for surpassing the issue. Based on the research, the problem related to waste of time has happened with the existing of modern technology. This research leads to attempt for Malaysian culture to commercialise and change the citizens' perception which think that traditional games are boring.

The advantages of playing the games are; people can spend the time by playing it; the games tighten the relationship of the societies, it can be played with many players despite the races, genders, or ages; it also apply teamwork among the players; it do not need expensive equipment or electricity to play; and finally, traditional games foster traditional values among the present generation. Thus, every generation must respect the cultural heritage as a traditional form of the game will create honorable generations in the future.

Malaysian Dam Haji (checkers) game is different from other checker games because it is developed using Malaysians dam haji rule which the king can move one step forward or backward on the check block. It can be played by anyone; adult or children. The idea of developing this game comes because of lack traditional game in the internet being developed so that young Malaysians get interested in playing traditional games. Briefly, to play the game we need two players, a checkerboard with black and red block, and twenty-four pieces of checkers; twelve on each side of the checkerboard. Each player will compete on one another and take out all opponents' pawn. 
When all the pawn or king of any side is out of the game, the leftover player will be stated as the winner. In dam haji game, a pawn can evolve to a king or "haji" when any pawns reach the end site of the checkerboard, this statement as reported by Rosli (2005).

Ceper (bottle steel cap) is a popular game around 19701980. This game is also known as jentik tutup botol, tutup oren, or kempyeng. It contains five (5) steel caps or ceper and needs more than one player to make this game more exciting and interesting. The player determines the rotation by lob action. The player who lobs the cap and gets a big number of caps, get the advantage to start the game first. The player will spin the ceper to play. Each piece of ceper must not overlap. If the allocation meets the criteria of the rule, the game can continue by taking one of the ceper which is scattered. If the chosen have been made, the other players need to decide which ceper should be flipped (CCt, 2013).

Batu Seremban (tossing stone) also known as Serembat or Selambut is usually played by girls individually or in groups of two to five people. Seremban game only needs a few pieces of fruit. Rubber seeds, pebbles or small stones, chunks of other objects commonly used round, often as much as five seeds. In addition, the cloth bag that sewn and filled with saga seeds, sand, etc. are also used. The game is often played at leisure, on the porch of the house, in the house, in the park or anywhere else that there is a clean and flat surface. The players sit on the floor and play in turns (CCt, 2013).

Gasing (tops spinning) is a popular traditional game among Malay. They were popular especially among the villagers in the State of Kelantan and Melaka. Each season after the rice harvest, several villagers will come together to challenge each other in an ultimate test of skill. The villagers believed that the gasing would help bring a good harvest. Both adults and children can play the game. But bigger or giant gasing is more of a game for adults rather than children. The one used by adults are much bigger in size and can spin for a period of time whereas the one played by kids are smaller. Gasing is split into two (2) categories. One is for ornamental purposes and while the other is for playing. There's no fixed number of players and the game can be played either in a team or individual. A circle is first drawn on the ground marking the circumstances of which the top is to spin. A player holds the top in his hand and grips the loose end of the string between the fingers and throws the top in the circle while at the same time pulls the string backward which sends the top into a spinning action. The one who's top spins the longest and within the specified circle becomes the winner. Once the top spins out the circle, the player loses the game. There are actually five (5) different shapes of gasing found in Malaysia namely: Plate-Shaped, Heart-Shaped, Hat Top, Egg-Shaped, and Berembang-Shaped. Berembang is a fruit of a seaside tree as had been detailed by Rashdan (2015).

Guli (marble) is also known as Kelering. One game involves drawing a circle in the sand, and players will take turns knocking other players' marbles out of the circle with their own marble. This game is called ringer but is also known by other names. Other versions involve shooting marbles at target marbles or into holes in the ground. The main goal is to end up with the most marbles at the end of the game. Each player brings his personal set of marbles to use and potentially lose. This is considered playing "for keeps" or "keepsies". Draw a circle measuring 10 feet in diameter (according to tournament rules) and a starting or "lag" line. The lag line is drawn just outside of the circle or "ring" and play at the field. Players use a shooter marble, which is larger than the others, to knock opponent marbles out of the ring. Players win any marbles they knock out. The player with the most "won" marbles wins the game. Players can also win marbles by knocking out another player's shooter marble, thereby collecting all of that player's "won" marbles as described by Ing (2015).

\section{METHOD}

The main materials in this box of traditional games are dam haji (checkers), ceper (bottle steel cap), batu seremban (tossing stone), guli (marble) and gasing (tops spinning). The box also uses a wooden pallet to accommodate all traditional games inside the box, which is divided into five (5) parts of small storage / slot as shown in Figure 1 (Fig.1). This handmade box is a prototype, not to be commercialized, only for the research purposes.

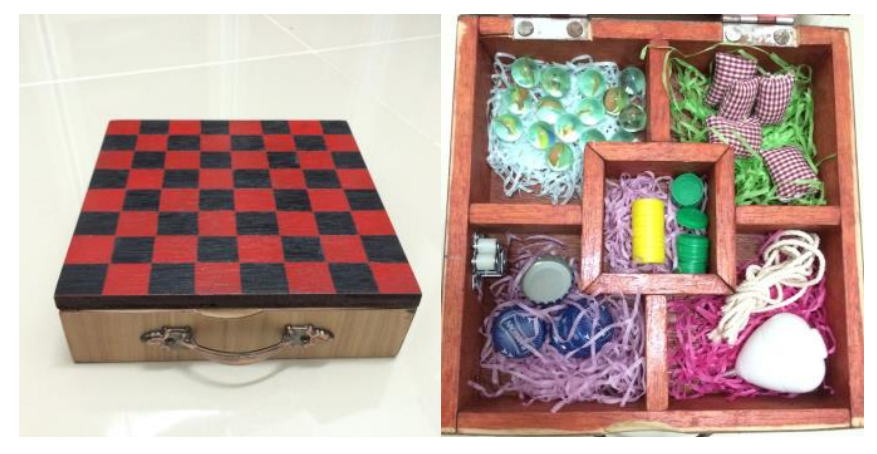

Fig.1. Box of Traditional Games; internal and external

The researchers used questionnaire as a survey for the analysis. Respondents are chosen among students, lecturers, local people and tourists from age 10 to 50 years old. The questionnaire of the box of traditional games involves pattern, colour, type of games and the appearance. The scale for marking used is from score ' 1 ' represents very bad, ' 2 ' represents bad, ' 3 ' represents moderate, '4' represents good and ' 5 ' represents excellent.

For the way of packaging, the respondents had experienced to have a brief look on the box of traditional games and to comment and evaluate the size and the basic elements of the games in the box. The statistical analysis generated using Statistical Package for the Social Sciences 10.0, includes analysis of mean, chi-square, cross tabs and descriptive. For packaging methods, on the other hand, the respondents supplied with the box of traditional game, where the size of the box as well as the design appearance of the box inside and outside as a basis of the assessment by each respondent. 


\section{FINDING AND DISCUSSION}

It is very simple to use this box of traditional games; users who first received this product set will be supplied with one (1) box with five (5) slots of traditional games inside. This game can run without having to wait to fill every corner of the box with players but can still work even if only with two (2) participants. When opened, there are also rules on condition included, ensuring that the game remains unique and attractive for all time, anyway or anyplace.

Statistical analysis descriptive used to build the relationship between the traditional games to the box of traditional games products users. There are 50 respondents were selected to evaluate and give comment about this product. Out of the total numbers, 18 respondents $(36 \%)$ were male and the rest are about 32 respondents (64\%) is female. Among the matters asked in the sensory tests are covering the level of respondent's fondness for the quality, taste, value, appearance, and texture. The goal is to get any improvement of the box of traditional games. Findings of the surveys discover that some of the research questions have a significant difference in gender, occupation and race.

In chi-square test analysis with p-value 0.10 which there are people can play easily, where all of the popular games of local people can be found only in a box, it saves the game room, easy to carry and very flexible. This option represents a different respondent opinion about such things possible because of differences in gender and age affects one's interest to play these games. "Easy" here gives meaning to the game is easy to access in one place in a box, not mixed and messy as ever, as shown in Table I.

TABLE I

\begin{tabular}{|c|c|c|c|c|}
\hline \multicolumn{2}{|r|}{ Gender } & Value & $\mathrm{df}$ & $\begin{array}{c}\text { Asymp. Sig. } \\
\text { (2-sided) }\end{array}$ \\
\hline \multirow{4}{*}{ Male } & Pearson Chi-Square & $5.850^{\mathrm{b}}$ & 6 & .440 \\
\hline & Likelihood Ratio & 7.187 & 6 & .304 \\
\hline & $\begin{array}{c}\text { Linear-by-Linear } \\
\text { Association }\end{array}$ & .152 & 1 & .696 \\
\hline & $\mathrm{N}$ of Valid Cases & 18 & & \\
\hline \multirow{4}{*}{ Female } & Pearson Chi-Square & $16.918^{\mathrm{c}}$ & 6 & .010 \\
\hline & Likelihood Ratio & 19.427 & 6 & .003 \\
\hline & $\begin{array}{l}\text { Linear-by-Linear } \\
\text { Association }\end{array}$ & 1.051 & 1 & .305 \\
\hline & $\mathrm{N}$ of Valid Cases & 32 & & \\
\hline \multirow{4}{*}{ Total } & Pearson Chi-Square & $8.172^{\mathrm{a}}$ & 6 & .226 \\
\hline & Likelihood Ratio & 8.961 & 6 & .176 \\
\hline & $\begin{array}{c}\text { Linear-by-Linear } \\
\text { Association }\end{array}$ & .299 & 1 & .585 \\
\hline & $\mathrm{N}$ of Valid Cases & 50 & & \\
\hline
\end{tabular}

In the other hand, a tendency of participants on the assumption attempts to play this product for the first time can attract players to try other traditional games with p-value 0.033 as shown in Table II. This decision may happen because every game has different techniques and strategies while playing as it's cannot be associated with other types traditional games. This also means this product can also attract tourist to play the traditional games. Meanwhile, though most men are less concerned about the game in the door because they think it does not sweat and less active than girls, more animating for each game's movement. In the other aspects, based on Thomas and Brown (2007) said the games play and learning have merged in fundamental to develop ways of thinking even different types of games.

TABLE II

\begin{tabular}{|c|c|c|c|c|}
\hline \multicolumn{2}{|c|}{ Gender } & Value & df & $\begin{array}{c}\text { Asymp. Sig. } \\
(2 \text {-sided })\end{array}$ \\
\hline \multirow{4}{*}{ Male } & Pearson Chi-Square & $13.714^{\mathrm{b}}$ & 6 & .033 \\
\cline { 2 - 5 } & Likelihood Ratio & 17.540 & 6 & .007 \\
\cline { 2 - 5 } & $\begin{array}{c}\text { Linear-by-Linear } \\
\text { Association }\end{array}$ & 5.636 & 1 & .018 \\
\cline { 2 - 5 } Female & N of Valid Cases & 18 & & .198 \\
\hline & Pearson Chi-Square & $8.593^{\mathrm{c}}$ & 6 & .160 \\
\cline { 2 - 5 } & Likelihood Ratio & 9.250 & 6 & .264 \\
\cline { 2 - 5 } & $\begin{array}{c}\text { Linear-by-Linear } \\
\text { Association }\end{array}$ & 1.248 & 1 & .228 \\
\cline { 2 - 5 } Total & N of Valid Cases & 32 & & .085 \\
\cline { 2 - 5 } & Pearson Chi-Square & $8.140^{\mathrm{a}}$ & 6 & .251 \\
\cline { 2 - 5 } & Likelihood Ratio & 11.097 & 6 & \\
\cline { 2 - 5 } & $\begin{array}{c}\text { Linear-by-Linear } \\
\text { Association }\end{array}$ & 1.318 & 1 & \\
\cline { 2 - 5 } & N of Valid Cases & 50 & & \\
\hline
\end{tabular}

Lastly is whether it's safe for children, there is significant difference with $\mathrm{p}=0.28$ is also about the question that the game is safe for children as shown in Table III. In product's demonstration, respondents were on average by $60 \%$ think this product can be marketable in this new era to attract of respondent while $48 \%$ of respondents have chosen excellent as they will enjoy playing the box of traditional games of quality is obtained with the frequency results of $90 \%$. $80 \%$ respondents also agreed with the appearance of a box of traditional games suitable with the innovation of wood's waste. A smooth texture but a little crumble to attract respondents was agreed by $74 \%$ of respondents while $26 \%$ of respondents are lightly agreed about the texture of the product.

TABLE III

\begin{tabular}{|c|c|c|c|c|}
\hline \multicolumn{2}{|c|}{ Gender } & Value & df & $\begin{array}{c}\text { Asymp. Sig. } \\
(2 \text {-sided })\end{array}$ \\
\hline \multirow{4}{*}{ Male } & $\begin{array}{c}\text { Pearson Chi- } \\
\text { Square }\end{array}$ & $14.167^{\mathrm{b}}$ & 6 & .028 \\
\cline { 2 - 5 } & Likelihood Ratio & 18.729 & 6 & .005 \\
\cline { 2 - 5 } & $\begin{array}{c}\text { Linear-by-Linear } \\
\text { Association }\end{array}$ & 6.543 & 1 & .011 \\
\cline { 2 - 5 } Female & N of Valid Cases & 18 & & \\
\hline \multirow{5}{*}{ Total } & $\begin{array}{c}\text { Pearson Chi- } \\
\text { Square }\end{array}$ & $10.345^{\mathrm{c}}$ & 6 & .111 \\
\cline { 2 - 5 } & Likelihood Ratio & 13.306 & 6 & .038 \\
\cline { 2 - 5 } & $\begin{array}{c}\text { Linear-by-Linear } \\
\text { Association }\end{array}$ & 1.437 & 1 & .231 \\
\cline { 2 - 5 } & N of Valid Cases & 32 & & .944 \\
\cline { 2 - 5 } & $\begin{array}{c}\text { Pearson Chi- } \\
\text { Square }\end{array}$ & $1.715^{\mathrm{a}}$ & 6 & .943 \\
\cline { 2 - 5 } & Likelihood Ratio & 1.729 & 6 & .704 \\
\hline & $\begin{array}{c}\text { Linear-by-Linear } \\
\text { Association }\end{array}$ & .145 & 1 & \\
\cline { 2 - 5 } & N of Valid Cases & 50 & & \\
\hline
\end{tabular}

The suggestions and other improvements are derived from the recommendations included in the questionnaire provided, it was found that most of the respondents recommend that monitoring of the needs of customers to add value this product 
is made so as to be commercialized in the category of small and medium enterprises before strategically marketed. However, this product is potentially made more in quality improvement research and the box of traditional game can be sold to any gift providers and provide local souvenir product variations to generate the household economy. Therefore, the commercialisation of the box of traditional game external market to boost research activities of deemed useless materials are conserving the environment as studied by (Daniel, 2004; Falk, 2002). Another aspect, the traditional game can be provided a great networking in strengthening the cultural and civic. Traditional games are so close to the culture of the local community and they internalize the values like cooperation, understanding, thoughtful, solve problems and fill their spare time hobby as was agreed by Grant (2006). According to Karlyn (2005), the creation of this game through a good research and observation can increase creativity in the mind development which strengthens the quality of learning for all ages.

\section{CONCLUSION AND SOLUTION}

Md. Jais Sarday said traditional games can be commercialised to attract tourist to come to Malaysia other than popular tourist destination. Christian Desrosiers, a tourist who come to Malaysia and stayed at Malaysian homestay, also admitted that traditional games are very interesting to the country because of the uniqueness of the game. (Mohd. Khairul, 2014)

Box of traditional games is for helping the Malaysian and also foreign tourists to know the traditional cultures. The product innovation can also avoid the $\mathrm{Y}$ generation from wasting their time with non-benefit matter especially by using modern technology all time such as social media. Actually, besides $\mathrm{Y}$ generation, the old generation has also tended to technology. This product can attract tourist from other countries to play traditional games together among the Malaysian. This can also be one of the methods to maintain and bring the culture of this game back to the future. In term of future improvement, the material can be changed to different types of material and not solely based on the wood. For example, plastic materials are a good potential as a body foundation. It is also can create variety pattern or colours for the product to make it more attractive. A proactive promotion on advertising through social networking is a good strategy to make it marketable. This product is chosen because it maintains the authenticity of the traditional heritage. So, to look forward to the future competence, another commercials name for the product could be proposed to the international market.

In fact, informally the Malaysia's Pahang State Tourism Board is looking forward to discuss with the researchers and the polytechnic to work further in using the box as a tourist souvenir during the campaign of Visit Pahang Year 2017. The overall conclusion of the study showed that the box of traditional games has a high chance to penetrate the market in Malaysia and abroad. Hopefully, these traditional games stored in this innovative box will be played and not be forgotten by our next generation.

\section{REFERENCES}

[1] CCt. (2013, March 19). "Tossing Stone / Batu Seremban". Retrieved from http://gerakgasing.blogspot.my/2013/03/batu-seremban_19.html

[2] CCt. (2013, March 19). "Bottle Steel Cap / Ceper / Tutup Botol". Retrieved from http://gerakgasing.blogspot.my/2013/03/ceper-tutupbotol.html

[3] Daniel, R. (2004). "Hands-on Activities for Innovative Problem Solving". Paper presented at the Proceedings of the 2004 American Society for Engineering Education Annual Conference and Exposition.

[4] Falk, R. H. (2002). "Wood-framed building deconstruction: A source of lumber for construction?” Forest Products Journal, 53(3), 8-15.

[5] Grant, J. (2006). "Sport, Culture and Society". New York: Routledge.

[6] Ing, H. H. (2015). "Marble / Guli”. Retrieved from https://browniesmpu.wordpress.com/2015/01/18/guli-hing-hong-ing/

[7] Karlyn, A. (2005). "The Sources of Innovation and Creativity". NCEE.

[8] Lya. (2012, September). "Types of Games". Retrieved from http://traditionalgamesinmalaysia.blogspot.my/p/types-of-games.html

[9] Mohd Hafiz, M. Y., \& Wan Mohammad Fauzi, S. (2013). "Modul Teras Sukan”. Kuala Lumpur: Majlis Kokurikulum Universiti-Universiti Malaysia (UniCC), Kementerian Pengajian Tinggi.

[10] Mohd. Khairul Mohd. Ali (2014, February 6). "Uniqueness Become Visitor Attraction / Keunikan Jadi Tarikan Pengunjung”. Retrieved from http://ww1.utusan.com.my/utusan/Johor/20140206/wj_05/Keunikanjadi-tarikan-pengunjung

[11] Rashdan. (2015). "Tops Spinning / Gasing". https://browniesmpu.wordpress.com/2015/01/18/gasing/ Retrieved from https://browniesmpu.wordpress.com/2015/01/18/gasing/

[12] Rosli, M. F. (2005). "The Development Of The Checkers / Dam Haji Traditional Game Using Java”. Kolej Universiti Teknikal Kebangsaan Malaysia.

[13] Thomas, D., \& Brown, J. S. (2007). "The Play of Imagination: Extending the Literary Mind". Games and Culture, 2(2), 149-172. doi:10.1177/1555412007299458

[14] Utusan (2015, December 13). "Maintaining Traditional Games as an Identity / Kekalkan Permainan Tradisional Sebagai Identiti”. Retrieved from http://www.utusan.com.my/berita/nasional/kekalkan-permainantradisional-sebagai-identiti-1.168402 